\title{
Serological Investigation of Bluetongue Virus Infection by Enzyme Linked Immunosorbent Assay (ELISA) in Sheep in Konya Region
}

\author{
Gulsen Yigit (Corresponding author) \\ Selcuk University, Faculty of Science, Department of Biology, Konya, Turkey \\ E-mail: yigitgulsen81@gmail.com.tr \\ Rustem Duman \\ Selcuk University, Faculty of Science, Department of Biology, Konya, Turkey \\ E-mail: rduman@selcuk.edu.tr
}

This work was financially supported by the Selcuk University Scientific Research Projects Coordinator ship (Project number: 08201028). This article has also been extracted from MS thesis of Gulsen YIGIT

\begin{abstract}
Of ovine breeding has a special importance in Turkey's economy. In this sector to date, there have been major problems from production to consumption. Among these, animal husbandry and disease problems have always been up to date. Some of the most important factors that negatively affect sheep breeding are the decrease in yield characteristics, medical inputs for treatment, and diseases caused by viruses that can cause significant economic losses resulting in mortality in animals. Blue Tongue virus infection also causes great economic losses in sheep, cattle and goats. In this study, blood samples were collected from clinically healthy not vaccinated 460 sheep by random sampling method in some closed livestock model applied in and around Konya. The presence of blue tongue virus antibodies in the prepared sheep blood sera was investigated by competitive ELISA(c-ELISA) technique. All samples were run in duplicate, with known positive and negative controls included in each test plate. The optical density (OD) of each plate well was determined at $620 \mathrm{~nm}$ wavelength. As a result of the study, $46(10 \%)$ of 460 sheep sera had BTV-specific antibodies. The study is important in terms of revealing the seroprevalence of the infection investigated by c-ELISA in blood serum taken from sheep in and around Konya.
\end{abstract}

Keywords: Bluetongue virus (BTV), Sheep, Serology, c-ELISA.

DOI: $10.7176 / \mathrm{JSTR} / 5-7-04$

\section{Konya Bölgesindeki Koyunlarda Mavidil Virus Enfeksiyonunun Enzyme Linked İmmunosorbent Assay ile Serolojik Araştırılması}

Özet

Koyun yetiştiriciliğinin Türkiye ekonomisinde özel bir önemi vardır. Bu sektörde günümüze kadar, üretimden tüketime büyük sorunlarla karşılaşılmıştır. Bunlar arasında, yetiştiricilik ve hastalık sorunları daima güncelliğini korumuştur. Koyun yetiştiriciliğini olumsuz yönde etkileyen faktörlerin en önemlilerinden bazıları, verim özelliklerinde azalma, sağaltım için medikal girdiler, hayvanlarda mortalite ile sonuçlanan önemli ekonomik kayıplara neden olabilen virusların yol açtı̆̆ hastalıklardır. Mavi Dil (Bluetongue virus, BTV) virus enfeksiyonunun koyunlarda, sığırlarda ve keçilerde büyük ekonomik kayıplara neden olduğu bilinmektedir. Bu çalışmada, Konya ve çevresinde kapalı işletme modeli uygulanan bazı özel hayvancılık işletmelerinde bulunan klinik olarak sağlıklı, aşılanmamış, 460 adet koyundan tesadüfi örnekleme metodu ile kan örnekleri toplandı. Hazırlanan koyun kan serumları

27 I $P$ a g e

www.iiste.org 
kompetitif ELISA (c-ELISA) tekniği ile mavidil virusu antikorları yönünden kontrol edildi. Her bir test pleytine bilinen pozitif ve negatif kontroller dahil edilerek bütün örnekler iki gözde çalşsıldı. Her bir gözün optik dansitesi (OD), $620 \mathrm{~nm}$ dalga boyunda belirlendi. Araştırma sonucunda, 460 koyun serumunun 46'sında (\%10) BTV'ye özgü antikor varlığı saptandı. Çalışma, Konya ve çevresindeki koyunlardan alınan kan serumlarında c-ELISA ile araştırılan enfeksiyonun, bölgedeki seroprevalansını ortaya koyması bakımından önem taşımaktadır.

Anahtar Kelimeler: Mavidil Virusu, Koyun, Seroloji, c-ELISA

\section{Giriş}

Hastalık ilk kez 18.yy'ın sonlarına doğru Fransız biyolog Francois Vaillant tarafindan, koyun ve sığırlarda görülen, 'tong-sikte' olarak adlandırılırken (Gutsche 1979, Mellor ve ark. 2009) 40 y1l sonra Duncan Hutcheon, hastalığı koyunlarda görülen 'malarial catarrhal fever' olarak adlandırmıştır (Hutcheon 1902 Mellor ve ark. 2009). 1905 yılında ise Spreull, hastalı̆̆ın yüksek ateşle başladığını, 7 10 gün sonra ağızda belirgin lezyonların görüldüğü ve dilin renginin koyu maviye dönüştüğünü gözlemleyerek hastalı̆̆ın adının 'bluetongue' olarak değiştirilmesi gerektiğini öne sürmüştür (Spreull 1905, Mellor ve ark. 2009). BTV her ne kadar Afrika hastalığı olarak nitelendirilse de, virus 1943 yılında Kıbrıs'ta 2500 koyunun ölümüne neden olmuştur. Hemen akabinde 1944, 1946 ve 1947 yıllarında Filistin, Türkiye ve İsrail'de hastallk patlak vermiştir (Gambles 1949, Komarov ve Goldsmit 1951, Mellor ve ark. 2009). 20. yüzyılın başlarında ise hastalık hemen hemen tüm kıtalara yayılmıştır (Mellor ve Boorman 1995). 1996 yılında koyunlardaki mortalite oranının artmasıyla mavidil virusunun etkeni olduğu hastalık dünya çapında 3 milyar dolar kayba neden olan enzootik bir hastalık olarak tanımlanmıştır (Tabachnick 1996).

Mavidil virusu (Bluetongue virus, BTV) Reoviridae familyasından Orbivirus cinsi içerisinde yer alır (Barros ve ark. 2007). Virus 10 segmentli çift iplikli RNA genomundan oluşur (Wilson ve Mellor 2009). RNA segmentleri, 7 yapisal protein (VP1-VP7) ve 5 yapisal olmayan protein (NS1,NS2,NS3,NS3/A,NS4) kodlar (Van Dijk ve Huismans 1988, Belhouchet ve ark. 2011). Dış kapsid proteinlerindeki, özellikle VP2'deki varyasyon farklı serotiplerin ortaya çıkmasına neden olur ve virusun günümüzde 26 serotipi tanımlanmıştır (Huismans ve Erasmus 1981, Maan ve ark. 2011, Coetzee ve ark. 2012). BTV, özellikle bazı sokucu sinekler (Culicoides spp. - Diptera: Ceratopogonidae) aracilığ ile biyolojik olarak memeli konakçıları arasında nakledilmekte ve tüm ruminant türlerini de enfekte edebilmektedir. 1944 yılında Güney Afrika'da infekte koyunlardan hastalığa karşı duyarlı koyunlara yayabilme yeteneğinde olan bir Culicoides türü ilk kez keşfedilmiştir (Culicoides imicola). Bundan dolayı virusun dünyadaki dağılımı, sokucu sinek vektör türlerinin bulunduğu bölgelerle sinırlıken, bulaşma bu ergin vektörlerin aktif olduğu yılın belirli dönemleriyle sınırlıdır (Mellor 2001). BTV, çoğunlukla koyunlarda ara sıra sığırlarda ve bazı geyik türlerinde hemorajik hastalığa neden olmaktadır (Mertens ve ark. 2004). Ayrıca, belirli koyun ırkları ve bazı geyik türlerinde hastalık, şiddetli ve ekseriya fetal olabilirken, diğer birçok ruminant türünde enfeksiyon genellikle anlaşılamaz. Aslında, klinik hastalık derecesinin, hayvan ırkına ve türüne, virusun serotipi veya suşu ile çevrenin iyi tanımlanmamıș belirli özelliklerine (örneğin yüksek seviyede solar radyasyona maruz kalan koyunların, böyle muameleye maruz kalmayanlara göre daha şiddetli lezyon geliştirdikleri bilinmektedir) bağlı olduğu görülmektedir (Mellor 2001).

\section{Materyal-Metot}

\subsection{Kan örnekleri}

$\mathrm{Bu}$ araştırmada Konya bölgesindeki özel hayvancılık işletmelerinde bulunan klinik olarak sağ lıklı aşılanmamış 460 adet koyundan, serum hazırlamak amacıyla kan örnekleri toplandı.

\subsection{Kan serum örneklerinin hazurlanması}

Kan örnekleri, koyunların kuyruk venlerinden alınarak katkısız vakumlu sistem kan alma tüplerinde (vacutainers) muhafaza edildi. Örnekler bir gece boyunca $+4^{\circ} \mathrm{C}^{\prime}$ de tutuldu ve her bir örnek $30 \mathrm{dk}, 2500$ 3000 rpm' de santrifuj edildi. Santrifuj edilen kanların serumları alındı ve $30 \mathrm{dk}$ süreyle $56^{\circ} \mathrm{C}^{\prime}$ de bir su banyosuna konuldu, soğumaya bırakıldı ve daha sonra ihtiyaç duyuluncaya kadar $-20^{\circ} \mathrm{C}$ ' de saklandı.

\subsection{Kompetitif enzyme linked immunosorbent assay (c-ELISA)}

Hazırlanan koyun kan serumları kompetitif ELISA (c-ELISA) tekniği ile mavidil virusu (Bluetongue virus, BTV) antikorları yönünden kontrol edildi. Bu amaçla, VMRD Inc. (Pulman, ABD) firması tarafindan geliştirilmiş ticari c-ELISA kiti kullanıldı. Test, kit prosedürüne göre uygulandı. Her bir örnek 96 gözlü pleytlerde test edildi ve her bir pleyte bilinen pozitif ve negatif kontroller dahil edildi. Bütün

28 | $P$ a g e 
örnekler iki gözde çalışıldı. Her bir gözün optik dansitesi (OD), ELISA mikropleyt okuyucu (Anthos II, Anthos Labtec Instruments $\mathrm{GmbH}$, Austria) kullanılarak $620 \mathrm{~nm}$ dalga boyunda belirlendi. Test edilen serum örneklerinin OD'si negatif kontrolün OD değerinin \%50' sinden daha düşükse pozitif, serum örneklerinin OD’si negatif kontrolün OD değerinin \%50’ sine eşit veya daha büyükse negatif olarak kabul edildi.

\section{4. c-ELISA için ön hazırlık ve test prosedürü}

Teste başlamadan önce, serum örnekleri, ayraçlar ve 96 gözlü kültür kapları oda sıcaklığına getirildi. Kit komponentleri; A: antijenle kaplanmış pleyt (5 pleyt), B: pozitif kontrol (4mL), C: negatif kontrol (4mL) D: antikor-peroksidaz konjugat $(16 \mathrm{~mL})$, E: $50 \mathrm{X}$ yıkama solüsyonu konsantre $(60 \mathrm{~mL})$, F: substrat solüsyonu $(30 \mathrm{~mL})$, G: durdurma solüsyonu $(30 \mathrm{~mL})$ olarak ayarlanmıştır (Katalog No:287-5). Her bir kuyucuğa kontroller ve serum örnekleri dahil $25^{\prime}$ er $\mu$ l eklendikten sonra, pleytler kapakları kapatılmadan oda sicaklığında $15 \mathrm{dk}$ inkübe edildiler. İnkübasyondan sonra her bir göze 25 'er $\mu$ l antikor-peroksidaz konjugat (D) ilave edildi ve pleytler kapakları kapatılmadan oda sıcaklığında 15dk inkübasyona bırakıldılar. İnkübasyondan sonra bütün kuyucuklara her seferinde $1 \mathrm{X}$ yıkama solüsyonu konarak pleytler 3'er kez yıkandı ve yıkama ile kontroller ve serumlar uzaklaştırıldı. Yıkama işleminden sonra her bir kuyucuğa 50'şer $\mu 1$ substrat solüsyonu (F) eklendi. Substratın kuyucukların dibini kapladığından emin olacak şekilde oda sıcaklığında $\left(21-25^{\circ} \mathrm{C}\right) 15 \mathrm{dk}$ inkube edildi. Kuyucuklar boşaltılmadan her bir kuyucuğa 50'şer $\mu 1$ durdurma solüsyonu (G) eklendi ve içeriği karıştırıldı. Kuyucuklar boşaltılmadan 620 nm'de ELISA okuyucuda kuyucukların optik dansitesi belirlendi. Testin geçerliliği için negatif kontrollerin ortalaması, 0.300 'den daha büyük ve 2.000 'den daha küçük bir optik dansitede sağlarken pozitif kontrollerin ortalamasının da, negatif kontrollerin ortalamasından daha küçük ya da negatif kontrollerin ortalamasının \% 50 (yarısı)'ne eşit bir optik dansitede olduğu gözlemlendi.

\section{Araştırma Sonuçları ve Tartışma}

Konya bölgesinde kapalı işletme modeli uygulanan, özel hayvancılık işletmelerinde bulunan klinik olarak sağlıklı, BTV'ye karşı aşılanmamış 460 adet koyundan tesadüfi örnekleme metodu ile kan örnekleri alındı. Toplanan kan serumu örnekleri, ticari kompetitif-ELISA ile BTV'ye karşı antikor varlığ yönünden incelendi (Şekil1). Araştırma sonucunda, 460 koyun serumunun 46'sında (\%10) BTV'ye özgü antikor varlığı saptandı (Tablo1).

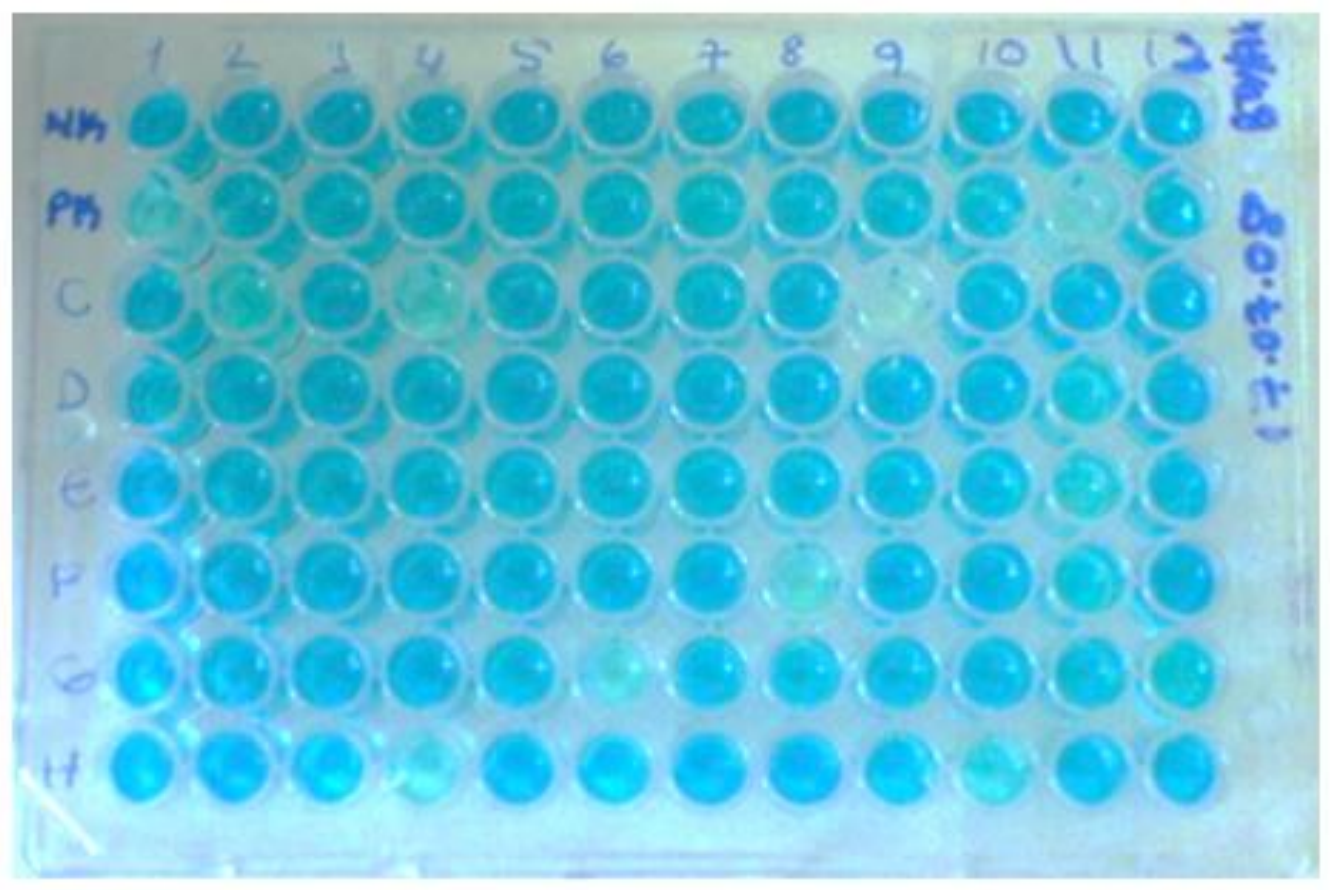

Şekil 1. ELISA sonuçları (reaksiyon durdurulduktan sonra) 
Tablo1. Örneklenen koyun serumları ve c-ELISA test sonuçları

\begin{tabular}{|c|c|c|c|c|}
\hline İşletmeler & $\begin{array}{c}\text { Toplam } \\
\text { hayvan sayısı }\end{array}$ & $\begin{array}{c}\text { Örneklenen } \\
\text { koyun sayısı }^{\dagger}\end{array}$ & $\begin{array}{c}\text { Seropozitif } \\
\text { koyun sayısı }^{\text {Soyur| }}\end{array}$ & $\begin{array}{c}\text { Seropozitif oranı } \\
\text { (\%) }\end{array}$ \\
\hline 1 & 200 & 20 & 0 & 0.00 \\
\hline 2 & 250 & 25 & 1 & 4.00 \\
\hline 3 & 250 & 25 & 1 & 4.00 \\
\hline 4 & 280 & 28 & 2 & 7.14 \\
\hline 5 & 300 & 30 & 3 & 10.00 \\
\hline 6 & 500 & 50 & 10 & 20.00 \\
\hline 7 & 280 & 28 & 2 & 7.14 \\
\hline 8 & 360 & 36 & 4 & 11.11 \\
\hline 9 & 230 & 23 & 0 & 0.00 \\
\hline 10 & 290 & 29 & 3 & 10.34 \\
\hline 11 & 340 & 34 & 4 & 0.00 \\
\hline 12 & 260 & 26 & 0 & 0.00 \\
\hline 13 & 260 & 26 & 0 & 13.33 \\
\hline 14 & 300 & 30 & 4 & 24.00 \\
\hline 15 & 500 & 50 & 12 & $\mathbf{1 0}$ \\
\hline Toplam & $\mathbf{4 6 0 0}$ & $\mathbf{4 6 0}$ & $\mathbf{4 6}$ & \\
\hline
\end{tabular}

$\dagger \% 10$ tesadüfi örnekleme metodu

Daha önce yapılan çalışmalarda SN (serum neutralization), AGID (agar gel immunodiffusion) ve cELISA yöntemlerinin BTV antikorlarının araştırılmasında daha hızl, hassas ve doğru sonuçlar verdiği bulunmuştur (Chander ve ark.1991, Patton ve ark.1994). c-ELISA ve AGID testleri serogrup-spesifik iken SNT ise tip-spesifiktir (Hamblin 2004). AGID testinin sensitivite eksikliği (Gustafson ve ark. 1991, Pearson ve ark. 1992) ve ayrıca diğer Orbivirus serogruplarıla, özellikle de epizootic haemorrhagic disease virusu (EHDV) ile gösterebildiği kross-reaksiyonlar nedeniyle (Pearson ve ark. 1992), testin geçmişten günümüze kadar gelen kullanımını tartışmaya açık kılmaktadır (Hamblin 2004). Son zamanlarda araştırmalarda BT (Bluetongue) serotipine özgü antikorları tespit etmede sıklıkla SNT yöntemi kullanılmakta, bu testin diğer Orbivirus serogruplarıyla kross-reaksiyon göstermediği için son derece hassas ve spesifik olduğu düşünülmektedir. Ancak bu test, zaman alıcı, ayıraçların pahalı olması ve test serumlarının kalitesinin hücreleri etkileyebilmesi nedeniyle rutin denemelerde genellikle kullanılmamaktadır (Hamblin 2004). Bu testin yerine, BT'nin kontrol amaçlı teşhisinde kullanılması tavsiye edilen c-ELISA'nın (OIE 2000) ise, AGID testinde olduğu gibi, EHDV ile kross-reaksiyon göstermeksizin, virusa karşı duyarlı ve spesifik olduğu bildirilmiştir (Osburn 1994). Bundan dolayı cELISA'nın daha hızlı ve ekonomik olması, bu testi, bir ülke veya bölgedeki aşılanmamış sığır ve koyunlarda BTV'nin dağılımını belirlemede ve enfekte olmayan hayvanlarda bir aşılama kampanyasının etkinliğini ölçmede araştırmacılar tarafindan tercih edilen bir metot haline getirmiștir (Hamblin 2004). BTV'nin Konya bölgesindeki koyunlarda c-ELISA ile seroprevalansını ortaya koymak amacı ile yapılan bu çalışmada, aşılanmamış koyunlar örneklendiği için, tespit edilen bu seropozitivite oranı (\%10) enfeksiyonun doğrudan göstergesi olarak kabul edilebilir.

Ekonomik etkisi yüzünden Office International des Epizooties (OIE) A listesine kaydedilmiş bir hastalık olan BT (OIE 2000), Hindistan (Bandyopadhyay ve Mallick 1983, Mehrotra ve ark. 1991, Ravishankar ve ark. 2005), Pakistan (Akhtar ve ark.1997), İran (Jafari Shoorijeh ve ark. 2008), Arnavutluk (Di Ventura ve ark. 2004),Bosna-Hersek (Velić ve ark. 2004), Kazakistan (Lundervold ve ark. 2004), ABD (Brako ve ark. 1984, Goyal ve ark. 1988), Meksika (Stott ve ark. 1989), Karayip ve Güney Amerika ülkeleri (Gibbs ve ark. 1983) gibi dünya ülkelerinde olduğu kadar, Türkiye'de de (Burgu ve ark. 1984, Bolat 1986, Öztürk ve ark. 1987, Girgin ve Yonguç 1988, Burgu ve ark. 1992, Yavru ve ark. 1999, Bulut ve ark. 2006, Gür 2008) özellikle koyun popülasyonunda oldukça yaygındır.

Türkiye'de BT enfeksiyonu ile ilgili ilk veriler 1944 yilına aittir (Anonymous1980). Daha sonraki yıllarda uzun bir süre Türkiye'de varlı̆̆ bilinmeyen BT enfeksiyonu 1977 yılının ekim ayında Aydın ve çevresinde bulunan 7 ildeki koyunlarda görülmüştür (Yonguç ve ark. 1982). BTV enfeksiyonuyla ilgili daha sonraki yıllarda yapılan çalışmalarda (Burgu ve ark. 1984, Bolat 1986, Öztürk ve ark.1987, Girgin ve Yonguç 1988, Burgu ve ark. 1992, Yavru ve ark. 1999, Bulut ve ark. 2006, Gür 2008) koyunlarda seropozitiflik oranının $\% 0-46$ arasında olduğu saptanmıştır. Burgu ve ark. (1984), Tahirova Devlet Üretme Çiftliği'ndeki 52 koyunda MNT ile gerçekleştirdikleri serolojik taramada, bütün serumların BTV

30 | P a g e

www.iiste.org 
antikorları yönünden seronegatif olduğunu rapor etmişlerdir. Bolat (1986), Türkiye'de Doğu ve Güneydoğu Anadolu bölgelerindeki 1290 koyundan elde ettiği kan serumu örneklerini SNT ve AGID testleri ile inceleyerek, 273 koyunu (\%21) BTV'ye karşı seropozitif olarak belirlemiştir. Öztürk ve ark. (1987), Konya Çiftlik Hayvanları Araştırma Merkezi’nden elde ettikleri 86 koyun serum örneğini incelemişlerdir. Araştırmacılar, SNT yöntemi ile bu serumları BTV SA 4 tipine karşı nötralizan antikorların varlığını belirlemek için kullanmışlardır ve \%36.04 seropozitiflik tespit etmişlerdir. Girgin ve Yonguç (1988), SNT ile Batı Anadolu bölgelerindeki koyunların \%46'sında ve keçilerin \%44'ünde BTV'ye karşı nötralizan antikor varlığı tespit etmişlerdir. Burgu ve ark. (1992), Türkiye'nin güney, güneydoğu ve ege bölgelerindeki illerden örnekledikleri koyun ve sığırlarda, BT seropozitiflik oranını, koyunlarda \%25.5 sığırlarda ise \%15.5 olarak belirlemişlerdir. Yavru ve ark. (1999), Bala Tarım İşletmesinden 115 adet sağlıklı koyundan topladıkları serum örneklerini MNT ile incelemişler ve 29'unu ( \%25.21) seropozitif bulmuşlardır. Bulut ve ark. (2006), Türkiye'nin Konya, Burdur illeri ve bu illerin civarlarındaki çiftlik hayvanlarından topladıkları toplam 562 adet koyun ve keçi kan serumu örneğini ELISA ve SNT ile mavidil virus antikorları yönünden incelemişlerdir. Konya'dan elde edilen 315 koyun serum örneğinden 54'ünü (\%17.1) ve Burdur'dan elde edilen 66 koyun serum örneğinden 1'ini (\%1.5) seropozitif olarak belirlemişlerdir. Gür (2008), Türkiye'nin güneydoğusundaki 82 adet ceylan, 684 adet koyun ve 100 adet sığırda BTV' ye spesifik antikorların varlığını ortaya koymak amacıyla gerçekleştirdiği çalışmada; ceylan, koyun ve sığırlarda seropozitivite oranlarını, sırasıyla, \%40.2, \%29.5 ve \%88 olarak saptamıştır. Bu çalışmada, Konya bölgesindeki özel hayvancılık işletmelerinde bulunan klinik olarak sağlıklı, aşılanmamış koyunlarda BTV'ye karşı c-ELISA ile \%10 oranında bir seropozitiflik tespit edilmiştir. Elde edilen bu oran (\%10), Bandyopadhyay ve Mallick'in (1983), Brako ve ark.'nın (1984), Stott ve ark.'nın (1989) Ravishankar ve ark.' nın (2005) sirasiyla \%11.6, \%13.3, \%9 ve \%8.25 oranında saptadıkları pozitif antikor varlığına yakın bir değer olarak görülmekle birlikte, dünyada (Gibbs ve ark. 1983, Mehrotra ve ark. 1991, Akhtar ve ark. 1997, Lundervold ve ark. 2004, Jafari Shoorijeh ve ark. 2008) ve Türkiye' de (Bolat 1986, Öztürk ve ark. 1987, Girgin ve Yonguç 1988, Burgu ve ark. 1992, Yavru ve ark. 1999, Bulut ve ark. 2006, Gür 2008) yapılan çalışmalarla elde edilen seropozitiflik oranlarından düşük, bazılarından ise (Burgu ve ark. 1984, Goyal ve ark. 1988, Di Ventura ve ark. 2004, Velić ve ark. 2004, Bulut ve ark. 2006) yüksektir. Lundervold ve ark. (2003), vektör dağılımı ve çokluğunun, enfeksiyon oranları ve yeterliliğinin ayrıca vektörün konakçı tercihlerinin, farklı seropozitivite oranları tespit edilmesinde önemli olabileceğini bildirmişlerdir. Diğer yandan, bu çalışmada elde edilen \%10 seropozitiflik oranının, çalışmanın yapıldığı Konya bölgesindeki koyunlarda önceden yapılan araştırmalarda (Öztürk ve ark. 1987, Yavru ve ark. 1999, Bulut ve ark. 2006) belirlenen seropozitivite oranlarından (sırasıyla \%36.04, \%25.1 ve \%17.1) düşük olduğu gözlenmiştir. Öztürk ve ark. (1987), bir yetiştirme çiftliğinden elde ettikleri kan serumlarını örneklemişler ve bizim çalışmamızda aynı bölgedeki koyunlardan elde edilen seropozitiflik oranından (\%10) daha yüksek bir seropozitiflik oranı (\%36.04) bulmuşlardır. Ancak, bizim örneklerimiz Konya bölgesindeki kapalı işletme modeli uygulanan özel hayvancılık işletmelerinde bulunan çiftlik hayvanlarından alınmıştır. Diğer taraftan araştırma bölgesinde belirlediğimiz seropozitivite oranının aynı bölgede Yavru ve ark. (1999) ile Bulut ve ark.' nın (2006) sirasıyla \%36.04 ve \%25.1 olarak belirledikleri seropozitiflik oranlarından düşük çıkmasının nedeni, özellikle son birkaç yıldır Tarım Bakanlığı Konya İl Müdürlüğü’nün BTV' nin eradikasyonu kapsamında bölgede uyguladığı sıkı kurallara (hayvan hareketlerinin sınırlandırılması ve bir sürüye hayvanların girişinin kontrol altına alınması, koyunculuk işletmelerinin enfeksiyona rezervuar teşkil eden sığırcılık işletmelerinden uzak yerlerde yüksek rakımlarda tesis edilmesi, hijyen kurallarına titizlikle uyulması, hastalık semptomları gösteren koyunların sağlıklı olanlardan ayrı tutulması, vs. gibi) ve bu bölgedeki özel koyunculuk işletmelerinin bu kurallara titizlikle uyması bağlı olabilir.

Mavidil virus enfeksiyonunun Konya bölgesindeki koyunlarda, seroprevalansını belirlemek amacıyla yapılan bu çalışmada, enfeksiyonun bölgedeki prevalansının azalmakta olduğu sonucuna varılmıştır. Enfeksiyonun yaygın olup olmaması; mevsimsel duruma, Culicoides 'lerin uçma zamanına, aşılamaya bağlıdır. Teste tabi tutulan koyunların aşılanmış olmamasına rağmen bölgedeki koyunlarda saptanan enfeksiyon prevalansındaki bu azalma; Tarım ve Köyişleri Bakanlığı Konya İl Müdürlüğü’ nün son birkaç yıldır BTV' nin eradikasyonu kapsamında öngördüğü uygulamalara ve bölgedeki özel hayvancılık işletmelerinin bu uygulamalara sıkı sıkıya uymasına bağlı olabilir. Asıl önemlisi, Tarım ve Köyişleri Bakanlığg Konya İl Müdürlüğü’ nün KKKA' nın eradikasyonu kapsamında öngörülen ilaçlama programı sonucunda kullanılan insektisitlerin, kenelerin yanında BTV' nin vektörü olan Culicoides türlerinin de sayıca azalmasına yol açmasına ve dolayısıyla BTV enfeksiyonunun yayılımı üzerinde direkt olarak etkili olabilmesine de bağlı olabilir. Bölgede kaydedilen enfeksiyon prevalansındaki bu azalmaya rağmen, bölgede ve ülkemizde enfeksiyonun tamamen eradike edilebilmesi için, yukarıda bildirilen uygulamaların devam ettirilmesi yanında, bir an önce uygun aşı serotipinin belirlenerek aşılama kampanyaları başlatılmalıdır. Ülkemizde uygulanan aşılama programlarına rağmen hala enfeksiyonun

31 | P a g e 
tekrar tekrar ortaya çıkması, kullanılan aşı serotipinin uygunluğu konusunda şüphe oluşturmaktadır. Bu nedenle tüm dünyada olduğu gibi ülkemizde de bir bölgedeki viral enfeksiyonlarla mücadele programında, etiyolojik ajanın tanısı yapılırken saha izolatlarının tespit edilmesi, tiplendirilmesi ve aşı suşunun buna göre seçilmesi büyük öneme sahiptir. Bu nedenle, PCR gibi ileri teknikler kullanarak sahadan mavidil virusunun identifiye edilmesi ve tiplendirilmesi yapılmalıdır ki, bunun aşı suşunun hazırlanmasında büyük önemi vardır.

\section{References}

Akhtar, S. Djallem, N., Shad, G., Thieme, O. (1997). Bluetongue virus in sheep flocks in North West Frontier Province, Pakistan. Prevent. Vet. Med., 29, 293-298.

Anonymous, (1980). Epizootiology, diagnosis and control of bluetongue in Turkey. Bull. Off. Int. Epiz., 92 (7-8), 567-574.

Bandyopadhyay, SK., Mallick, BB. (1983). Serological prevalence of bluetongue antibodies in India. Ind. J. Anim. Sci., 53(12), 1355-1356.

Barros, S.C., Ramos, F., Luis, A.V., Duarte, M., Henriques, M., Cruz, B., Fevereiro,M.( 2007). Molecular epidemiology of bluetongue virus in Portugal during 2004-2006 outbreak. Vet. Microbiol., 124,25-34.

Belhouchet, M., Mohd, J.F., Firth, A.E., Grimes, J.M., Mertens, P.P., Attoui, H. (2011). Detection of a fourth orbivirus non-structural protein. PLoS One 6, e25697.

Bolat, Y. (1986). Elazığ, Diyarbakır ve Şanlıurfa illerinde koyunların mavidil hastalığının yayılması üzerine serolojik araştırmalar. S. U. Vet. Fak. Derg., 2, 103-112.

Brako, E.E., Fulton, R.W., Nicholson, S.S., Amborski, G.F. (1984). Prevalence of bovine herpesvirus-1 bovine viral diarrhea, parainfluenza-3, goat respiratory syncytial, bovine leukemia and bluetongue viral antibodies in sheep. Am. J. Vet. Res., 45 (4), 813-816.

Bulut, O., Yavru, S., Yapkıç, O., Şimşek, A., Kale, M., Avcı, O. (2006). Serological investigation of bluetongue virus infection by serum neutralization test and elisa in sheep and goats. Bull. Vet. Inst. Pulawy, 50, 305-307.

Burgu, İ., Öztürk, F., Akça, Y. (1984). Tahirova devlet üretme çiftliği koyunlarında viral enfeksiyonlar üzerine serolojik araştırmalar. A. U. Vet. Fak. Derg., 31, 167-179.

Burgu, İ., Urman, H.K., Akça, Y., Yonguç A. D., Mellor, P. S., Hamblin, C. (1992). Serological survey and vector surveillance for bluetongue in southern Turkey. Proceedings of the 2nd International Symposium Bluetongue, African Horse Sickness and Related Orbiviruses. Walton, T. E., Osburn, B. I. (eds.), pp. CRC Press, Boca Raton, FL., 168-174,

Chander, S., Prasad, G., Jain, N.C. (1991). Dot immunobinding assay for the detection of bluetongue virus antibodies in sheep experimentally inoculated with bluetongue virus type-1. Vet Microbiol, 28, 289-294.

Coetzee, P., Stokstad, M., Venter, E.H., Myrmel, M., Vuuren, M.V. (2012). Bluetongue: A historical and epidemiological perspective with the emphasis on South Africa. Virology Journal, 9,198

Di Ventura, M., Tittarelli, M., Semproni, G., Bonfini, B., Savini, G., Conte, A., Lika, A. (2004). Serological surveillance of bluetongue virus in cattle, sheep and goats in Albania. Vet. Ital., 40 (3), 101-104.

Gambles, R.M. (1949) Bluetongue of sheep on Cyprus. J. Comp. Path. 59, 176-90. 
Gibbs, E.P., Greiner, E.C., Alexander, F.C., King, T.H., Roach, C.J. (1983). Serological survey of ruminant livestock in some countries of the Caribbean region and South America for antibody to bluetongue virus. Vet. Rec., 113 (19), 446-448.

Girgin, H., Yonguç, A.D. (1988). Türkiye'deki koyunların mavidil hastalığının serolojik, etiyolojik ve patolojik durumu üzerinde araştırmalar. Etlik Vet. Microbiol. Derg., 6, 13-24.

Goyal, S.M., Khan, M.A., McPherson, S.W., Robinson, R.A., Boylan, W.J. (1988). Prevalence of antibodies to seven viruses in a flock of ewes in Minnesota. Am. J. Vet. Res., 49 (4), 464-467.

Gustafson, G.A., Pearson, J.E., Moser K.M. (1991). A comparison of the bluetongue competitive ELISA to other serologic tests. In Bluetongue, African horse sickness and related orbiviruses (T.E. Walton \& B.I. Osburn, eds). Proc. Second International Symposium, Paris, 17-21 June (1991) CRC Press, Boca Raton 570-574.

Gutsche, T. (1979) There was a Man. Cape Town: Timmins, p. 4.

Gür, S. (2008). A serological investigation of bluetongue virus (BTV) in cattle, sheep and gazella subgutturosa subgutturosa in southeastern Turkey. Trop. Anim. Health Prod., 40 (3), 217-21.

Hamblin, C. (2004). Bluetongue virus antigen and antibody detection, and the application of laboratory diagnostic techniques. Vet. Ital., 40, 538-45.

Huismans, H., Erasmus, B.J. (1981). Identification of the serotype-specific and group-specific antigens of bluetongue virus. Onderstepoort J Vet Res., 48,51-58.

Hutcheon, D. (1902) Malarial catarrhal fever of sheep. Vet. Rec., 14, 629-33.

Jafari Shoorijeh, S., Ramin, A.G., Maclachlan, N.J., Osburn, B.I., Tamadon, A., Behzadi, M.A., Mahdavi M., Araskhani, A., Samani, D., Rezajou, N., Amin-Pou, A.( 2008). High seroprevalence of bluetongue virus infection in sheep flocks in West Azerbaijan, Iran. Comp. Immunol. Microbiol. Infect. Dis., In Press.

Komarov, A., Goldsmit, L. (1951) A disease similar to bluetongue in cattle and sheep in Israel. Refu. Vet., 8 96-100.

Lundervold, M., Milner-Gulland, E.J., O’Callaghan, C.J., Hamblin, C. (2003). First evidence of bluetongue virus in Kazakhstan. Vet. Microbiol., 92, 281-287.

Lundervold, M, Milner-Gulland, E. J., O’Callaghan, C. J., Hamblin, C., Corteyn, A., Macmillan, A. P. (2004). A serological survey of ruminant livestock in Kazakhstan during post-Soviet transitions in farming and disease control. Acta Vet. Scand., 45,211-224.

Maan, S., Maan, N.S., Nomikou, K., Batten, C., Antony, F., Belaganahalli, M.N. (2011). Novel bluetongue virus serotype from Kuwait. Emerg Infect Dis., 17,886-889.

Mehrotra, M.L., Singh, R.,Shukla, D.C. (1991). Seroepidemiology and isolation of virus from an outbreak of bluetongue (BT) in Tamil Nadu. Indian J. Anim. Sci., 61(12), 1282-1283.

Mellor, P.S., Boorman, J. 1995. The transmission and geographical spread of African horse sickness and bluetongue viruses. Ann. Trop. Med. Parasitol., 89,1-15.

Mellor, P.S. 2001. Bluetongue virus. The Encyclopedia of Arthropod-Transmitted Infections. Service, M. D. (ed), pp. CABI Publishing, Wallingford, Oxon,GBR., 78-83.

Mellor, D. J., Patterson-Kane, E., Stafford, K. J. (2009). Oxford, UK: Wiley-Blackwell. The sciences of animal welfare, 71-94. 
Mertens, P.P.C., Maan, S., Samuel, A., Attoui, H. (2004). Orbivirus, Reoviridae. Virus taxonomy, VIIIth report of the ICTV. Fauquet, C.M., Mayo, M.A., Maniloff, J., Desselberger, U., Ball, L.A. (eds.), pp. Elsevier/Academic press, London,UK., 466-483,

Osburn, B.I. (1994). The impact of bluetongue virus on reproduction. Comp. Immunol. Microbiol. Infect. Dis., 17, 189-196.

Öztürk, F., Yavru, S., Eröz, S.(1987). Koyunlarda mavi dil enfeksiyonu üzerine seroepizootiolojik araştırmalar. S. U. Vet. Fak. Derg., 6, 37-40.

Patton, J.F., Work, T.M., Jessup, D.A., Hietala, S.K., Oliver, M.N., Maclaclan, N.J. (1994). Serologic detection of bluetongue virus infection of black-tailed deer: comparison of serum neutralization, agar gel immunodiffusion, and competitive ELISA assays. 30, 99-102.

Pearson, J.E., Gustafson, G.A., Shafer, A.L., Alstad, A.D. (1992). Diagnosis of bluetongue and epizootic haemorrhagic disease. In Bluetongue, African horse sickness and related orbiviruses (T.E. Walton \& B.I. Osburn, eds). Proc. Second International Symposium, Paris, 17-21 June 1991. CRC Press, Boca Raton

533-546.

Ravishankar, C., Krishnan Nair, G., Mini, M., Jayaprakasan, V. (2005). Seroprevalence of bluetongue virus antibodies in sheep and goats in Kerala State, India. Rev. Sci. Tech. Off. Int. Epiz., 24(3), 953-958.

Spreull, J. (1905) Malarial catarrhal fever (bluetongue) of sheep in South Africa. J. Comp. Pathol. Ther., $\quad 18,321-37$.

Stott, J.L., Blanchard-Channell, M., Osburn, B.I., Riemann, H.P., Obeso, R.C. (1989). Serologic and virologic evidence of bluetongue virus infection in cattle and sheep in Mexico. Am. J. Vet., 50 (3), 335-340.

Tabachnick, W. J. (1996). Culicoides variipennis and bluetongue-virus epidemiology in the United States. Annu. Rev. Entomol., 41,23-43.

Van Dijk, A.A., Huismans, H. (1988). In vitro transcription and translation of bluetongue virus mRNA. J Gen Virol, 69,573-581.

Velić, L., Velić, R., Bajrović, T., Dukić, B.,Ćamo, D. ( 2004). Bluetongue in Bosnia: comparisons of competitive enzyme-linked immunosorbent assay and standard agar gel immunodiffusion tests. Vet. Ital., 40 (4), 562-563.

Wilson, A.J., Mellor, P.S. (2009). Bluetongue in Europe: Past, present and future. Phil. Trans. R. Soc. $B, 364,2669-2681$.

Yavru, S., Öztürk, F., Gürhan, İ., Şimşek, A., Ünver, G., Duman,R.,Yapkıç, O. (1999). Koyunlarda Solunum Yolu Viruslarının Serolojik Olarak Araştırılması. Hayv. Araş. Derg., 9 (1-2), 53-60.

Yonguc, A. D., Taylor, W. P., Csontos, L., Worrall, E. (1982). Bluetongue in western Turkey. Vet. Rec., 111,144-146. 